I found the chapter on the relationship between Brittain and Holtby the most convincing. Rather than attempting to claim or refute a lesbian relationship between the two writers, Clay, using previously unpublished correspondence, explores their mutually dependant, complex relationship. They had, she argues, a professional friendship that was shot through by erotic energies, a relationship that she calls 'a trade in work and desire'. Rather than speak of the emotion that underpinned their need for each other in terms of desire, they used a discourse of work and professionalism. A discourse that bound them together more firmly than any declaration of love could have done in an era when to speak of same sex love was to speak of inversion and therefore threaten their status as serious writers.

This text is on the whole compellingly argued and Clay draws on a wide range of sources to make her case. It will be useful to students of literary studies and the history of feminism in the interwar years. It evokes a period when some women had at last gained some of the freedoms they had been struggling for, yet had lost the 'innocence' that had surrounded same-sex friendships of an earlier era. Above all, it demonstrates most clearly that for feminists at this time the private was most certainly political in the broadest sense of that word.

doi: $10.1057 /$ fr. 2008.14

Gerry Holloway

\title{
White lives: the interplay of 'race', class, and gender in everyday life
}

Bridget Byrne; Routledge, 2006, 280p, ISBN 0-415-3471l-4 (Hbk), 0-415-34712-2 (Pbk), $£ 24.99$ (Pbk)

The current panic over the alleged failure of multiculturalism in Britain focuses attention on modish terms like 'social cohesion' and 'engagement with alienated youth' (read Muslims). In contrast, the idea that vast sections of the white middle class opt to live segregated lives in urban and rural parts of the country is seldom raised as a problem. Natasha Walter, author of The New Feminism, recently illustrated how middle-class parents routinely lied about their religious affiliations to get their kids into more exclusive church schools (2006). One mother she interviewed admitted to moving her daughter from a nearby state school where she was perfectly happy because of social pressure: 'As soon as I started talking to the other mothers like me that I met in the neighbourhood, I found that none of them would even consider sending their children there, and

that put me off'. At a time when the blame for faith-based separation is being laid at the door of minorities, this phenomenon, rarely discussed in public, suggests that the wrong people are being targeted for anti-social behaviour. 
Bridget Byrne's study White Lives is relevant to this problem because it is designed to understand how racism permeates everyday life in ways that are often unmarked. Her work is situated within the critical study of whiteness; she is concerned with the de-construction of the 'white metropolitan subject as normative'. Instead of drawing attention to the recognizable expressions of white supremacy articulated by British nationalists, she trawls through her interviews with twenty-five mainly white women living in two adjacent areas of South London to bring to light some of the ways in which 'race' intervenes in the way they behave, identify and reproduce themselves. She asks: 'How is it that dominant ideas of the commonsense and normal come to be overlaid with racialized conceptions that centre around whiteness?'

Byrne is not a social psychologist, but she is particularly interested in the way that ideas about racial difference circulate among women bringing up children in parts of the city that are culturally diverse. Paying her respects to a wide range of theoretical predecessors, such as Ruth Frankenberg's White Women, Race Matters (1993), (a progeny of feminism's hideous struggle with racism throughout the 1980s), and Judith Butler's work on gender as performance (which rethinks the emphasis on bodies as essence), Bridget Byrne approaches motherhood as a complicated set of practices that are inevitably raced, gendered and classed. The analytical lens is trained sympathetically on mothers not just as subordinates but also as relatively affluent participants struggling to live moral lives in the midst of deeply unjust social arrangements. Byrne's introduction offers a valuable review of the different approaches that have informed her project, showing how scholarly feminist imperatives to reveal the operations of power are absolutely integral to modern sociological thought.

It is the discussion of their children's schooling that provides the richest material for Byrne's analysis. Before we get to this, however, she supplies an honest, reflexive critique of her ethnographic methods and a thoughtful chapter on how her participants construct their subjectivities (or not). She is acutely sensitive to the silences, avoidances and changes of tone that characterize most of the discussions about 'race' which, she suggests, is a taboo subject. These sections alone make this a valuable text for teaching.

The central chapter on education teases out the contradictory ways in which the participants articulate the concept of cultural difference as it impacts on the educational choices they make for their children. Their attempts to rationalize or justify decisions to find schools that are the 'right' social mix reflect a widespread British revulsion at the prospect of being 'swamped' by people of apparently different cultures. This discussion contains few surprises but Byrne's patient analysis of this phenomenon shows how markers of racial and cultural difference are perceived in relation to all the other requisites of 'a good school'. 
In the penultimate chapter, Byrne pushes her subjects further, asking them to reflect on their sense of national identity. Here she suggests that her subjects' accounts of their own life stories are closely intertwined with their sense of what a national, collective narrative might be: 'As such, it was fluid and multiple' (p. 167). Her final chapter, written in 2005 , deals with the political implications of her pre-war fieldwork but here she admits why this reflexive work is unlikely to make the headlines. 'The book', she writes, 'has focused on how things are done as a preliminary move towards working out how they might be undone'. However, she leaves readers with the certainty that well-meaning white people cannot evade 'race' by thinking it has nothing to do with them.

\section{references}

Vron Ware

Frankenberg, R. (1993) White Woman, Race Matters: The Social Construction of Whiteness, Minnesota: University of Minnesota Press.

Walters, N. (1999) The New Feminism, London: Virago Press.

Walters, N. (2006) 'On a Wink and a Prayer' The Guardian, 14 July.

doi: $10.1057 / f r .2008 .15$

\section{The ethics of cultural studies}

Joanna Zylinska, Continuum, London and New York, 2005, ISBN 0-8264-7524-8£16.99 (Pbk)

Zylinska's is a very detailed and intricate consideration of ethics in cultural studies. Her analysis is framed within the history of cultural studies and some of the key texts; she draws on Derrida throughout but also engages with canonical authors such as Judith Butler, Donna Haraway, Stuart Hall, N. Katherine Hayles and Jean-Francois Lyotard, so that the reader can learn much about the field, as well as place Zylinska's work in a particular critical genealogy. However, the key contribution made by the book is to bring a new theoretical perspective to the issue of ethics in cultural studies - that of Levinas - and then to apply this to contemporary cultural problematics. It is important to understand that Zylinska's title refers to a very specific meaning of 'ethics' and this book is not about ethics in the generalized sense of moral principles; rather Zylinska proposes that cultural studies could gain much from a 'rigorous engagement' (p. 10) with the work of French philosopher Emmanuel Levinas for whom ethical responsibility comes from coming face-to-face with the Other. For Levinas, an encounter with the Other leads to an obligation without specific content; therefore ethics, in the sense Zylinska employs the term, cannot be a closed system filled with universal content. It is rather the response to alterity, the nature of which cannot be prescribed: 'The 